\title{
The Effects of Freight Vibrations on Slope Stability along the SH35, Bay of Plenty East, New Zealand
}

\author{
Angelo Indelicato \\ Stantec UK, Reading, UK \\ Email: angelo_indelicato@hotmail.com
}

How to cite this paper: Indelicato, A. (2020). The Effects of Freight Vibrations on Slope Stability along the SH35, Bay of Plenty East, New Zealand. Journal of Geoscience and Environment Protection, 8, 335-345. https://doi.org/10.4236/gep.2020.85021

Received: May 1, 2020

Accepted: May 26, 2020

Published: May 29, 2020

Copyright $\odot 2020$ by author(s) and Scientific Research Publishing Inc. This work is licensed under the Creative Commons Attribution International License (CC BY 4.0).

http://creativecommons.org/licenses/by/4.0/

\section{(c) (i) Open Access}

\begin{abstract}
State Highway 35 (SH35) connects Opotiki to Gisborne along the Raukumara Peninsula in the North Island, New Zealand. This corridor passes through an area which is prone to landslides, especially during the wet season. This, in turn, influences the traffic and has detrimental effects to the local economy, as it is dependent mainly on tourism and commercial transportation by road. This paper will focus on the landslides which occurred between June and September 2018, within the Bay of Plenty East on the north side of the Raukumara Peninsula. The paper will analyze both the nature and triggering mechanisms behind these landslides. As the landslides occur in the wet season, rainfall has been commonly considered the main trigger. However, the paper will argue that vehicle vibrations have been contributing to the instability of the slopes within the Bay of Plenty East. This paper will be instrumental in developing future transportation strategies in this part of the North Island.
\end{abstract}

\section{Keywords}

Landslide Trigger Mechanisms, Freight Vibration, Bay of Plenty East,

Raukumara Peninsula, New Zealand

\section{Introduction}

SH35 is the only road that connects the Raukumara Peninsula from Opotiki in the Bay of Plenty East (BOP), to Gisborne passing from East Cape (Figure 1). The road, which was originally a Maori designation road, was fully constructed in 1929. It is approximately $335 \mathrm{~km}$ long ( $2.9 \%$ of the total state highway network) with a total value of assets along the corridor of \$403 M New Zealand Dollar (New Zealand Transportation Authority, 2018). 


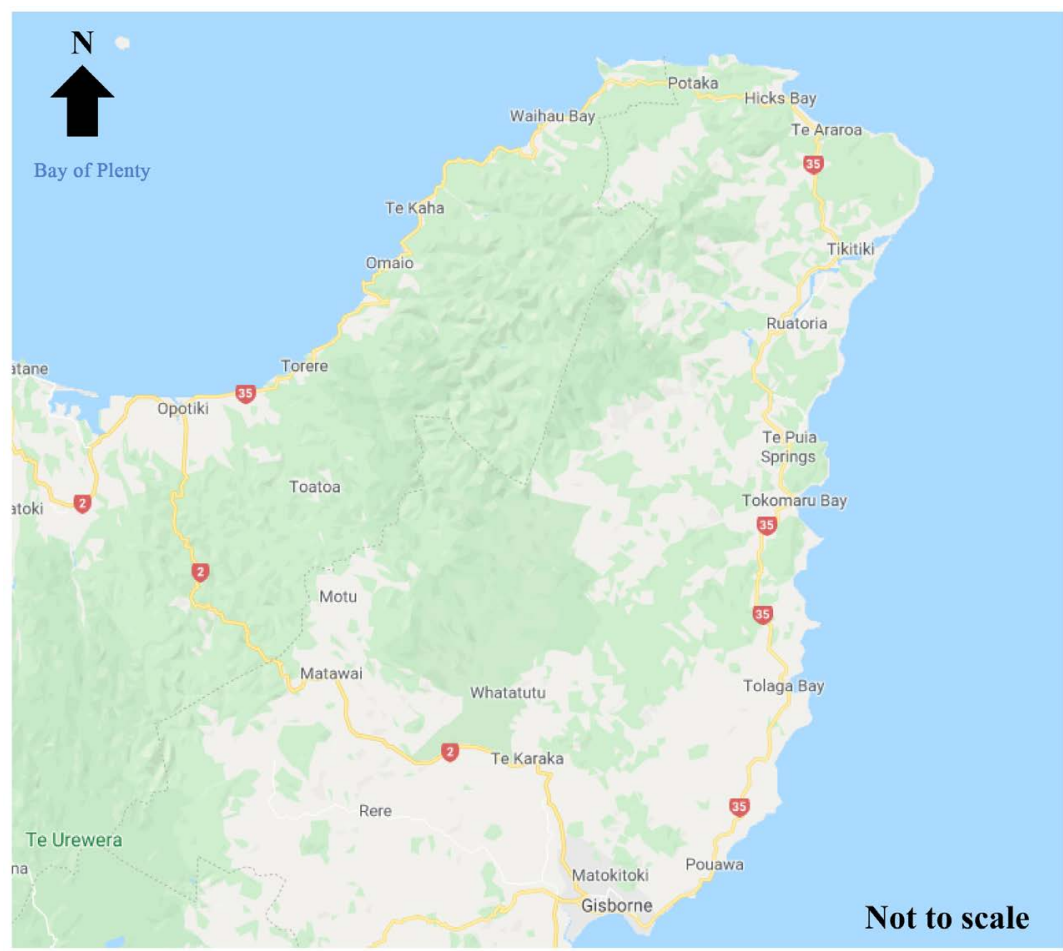

Figure 1. SH35 Location (@Google map 2020).

The corridor is consistent in nature with frequent bends and steep undulating topography and geometry. Population stagnation and economic decline has been a major concern for the area. For this reason, investment opportunities are available to reverse the negative trend. The key customers that utilize the corridor are, mainly, residents and freight operators. Furthermore, the proximity of surf beaches, nature trails, camping sites, and cycle tourism add to the pressure on the local road network.

This portion of the New Zealand (NZ) Highways has been affected continuously by landslides (note that these occur along the entire corridor). A deeper understanding of trigger mechanisms behind these landslides has the potential to minimize the likelihood of landslide recurrence.

\section{Methodology}

The methodology used in this paper will focus initially on the study of the landslides occurred in 2018 along the SH35 corridor. The slips will be compared with the rainfall data and earthquake events occurring within the same period to establish the correlation between the landslide triggering mechanism, and the slope failure. The vibration caused by the freight passage cannot be correlated with the landslide events as per their frequency along the state highway, however their influence will be taken into consideration.

\section{Geological Setting}

The generalized regional geology of the Raukumara Peninsula is based on the 
map published by Mazengarb (Mazengarb \& Speden, 2000).

Two thirds of the corridor were built on the Waioeka terrain. This formation consists mainly of indurated quartzofeldspathic, lithic sandstone, and mudstone known as "greywacke". This has been mapped as Torlesse Supergroup. Monotonous sequences of indurated, interbedded sandstone and mudstone that are typical of the Torlesse accumulate mainly in deep marine environments within an accretionary prism (Mazengarb \& Speden, 2000).

The Torlesse rocks are thrust over a younger Tikihore Formation. The contact point is visible near the mouth of the Raukokore River. The Tikihore Formation was deposited during the Tertiary. This formation is made of alternating finegrained sandstone, as well as mudstone with sandstone, and these, show typical normal grading. It has been suggested a submarine fan or fans in deep marine depositional environment for this Formation (Mazengarb \& Speden, 2000).

Close to Cape Runaway, lies a Pliocene rock Formation. It is a fossiliferous muddy sandstone with a thin basal conglomerate or limestone (i.e. Waikura Limestone).

Elevated marine terraces are commonly seen along the coast, between Opotiki and East Cape. These terraces represent erosion surfaces that were initially cut in bedrock by marine processes, and subsequently raised by a tectonic uplift to as high as $300 \mathrm{~m}$ above the present sea level. The terraces are commonly overlain by a thin deposit of gravel and sand, which are capped by younger tephra, loess, and other non-marine deposits (Ota et al., 1992).

Various faults also impact on the SH35. These run primarily East-West with a recurrence of between 3500 and 5000 years (e.g., Kereu Fault, Haparapara Fault, and Motu River Fault. GNS, 2018). Although they do not reoccur often, they still play an important role in the geology of the area.

\section{Climate}

The study area is sheltered by high country to the West, South and East. Day to day variations of the weather are largely determined by the direction of wind. Most of the area receives a large part of its annual rainfall during periods of onshore north to northeast winds. These airstreams frequently have long trajectories over the warm Ocean to the north of New Zealand and, as a result, the air flowing onto Bay of Plenty under these conditions, is very humid. These airstreams produce widespread and heavy rain. The pattern of rainfall distribution over the BOP largely reflects the region's exposure to the main rain-bearing north easterly winds. SH35 receive an average of $1300-1500 \mathrm{~mm}$ of rain per year (Chappell, 2013).

\section{Landslides in New Zealand}

\subsection{Classification and Terminology}

The landslide terminology used in New Zealand follows Cruden and Varnes (Cruden \& Varnes, 1996). However, different terms are commonly used with 
regards to the location of the slip according to the road location, i.e., over slips and under slips. In most cases that this research considers here, these consist of colluvium material deposited along the natural slope which has been cut to accommodate the $\mathrm{SH} 35$.

Over slips refer to the slope failure that takes place above the road level. Under the terminology from Hearn (Hearn \& Hunt, 2011), over slips also include erosion above the road (Sites 4 and 5) and rockfall above the road (Site 8).

Under slips are slope failures which develop below the highway road level, and, according to the Hearn classification, those earth movements are classified as erosion below the road (Hearn \& Hunt, 2011).

\subsection{Landslides along the SH35}

\subsubsection{Site 1}

Site 1 is an under slip located at circa $7.7 \mathrm{~km}$ East of Tirohanga (Figure 2). The first slip developed in 2016. The most recent slip surface occurred in early September 2018 (Figure 3). The scar is $6-7 \mathrm{~m}$ high and $13 \mathrm{~m}$ wide with a crown that is $0.85 \mathrm{~m}$ away from the edge line. The pavement has been undercut so that it is currently overhanging, (i.e. the slip surface is under the road surface). The slope is made of silty clayey sand with an occasional gravel from the Quaternary terrace deposit. Spring water is also present on the slipping surface.

\subsubsection{Sites 2 to 5}

Sites 2, 3, and 4 are located at approximately $5.5 \mathrm{~km} \mathrm{NNE}$ of Hawai (Figure 4).

Site 2 under slip occurred in mid-July 2018 (Figure 4) along the white edge line of the carriageway (Figure 5). The width is approximately $35 \mathrm{~m}$. Tension cracks measure up to $100 \mathrm{~mm}$ wide with vertical displacements below $80 \mathrm{~mm}$ in length. Based on the scouring on greywacke at the cut slope above the carriageway at road level, it is concluded that the slump area was likely within the water runoff flow path. There were visible signs of erosion at the base of the cut slope.

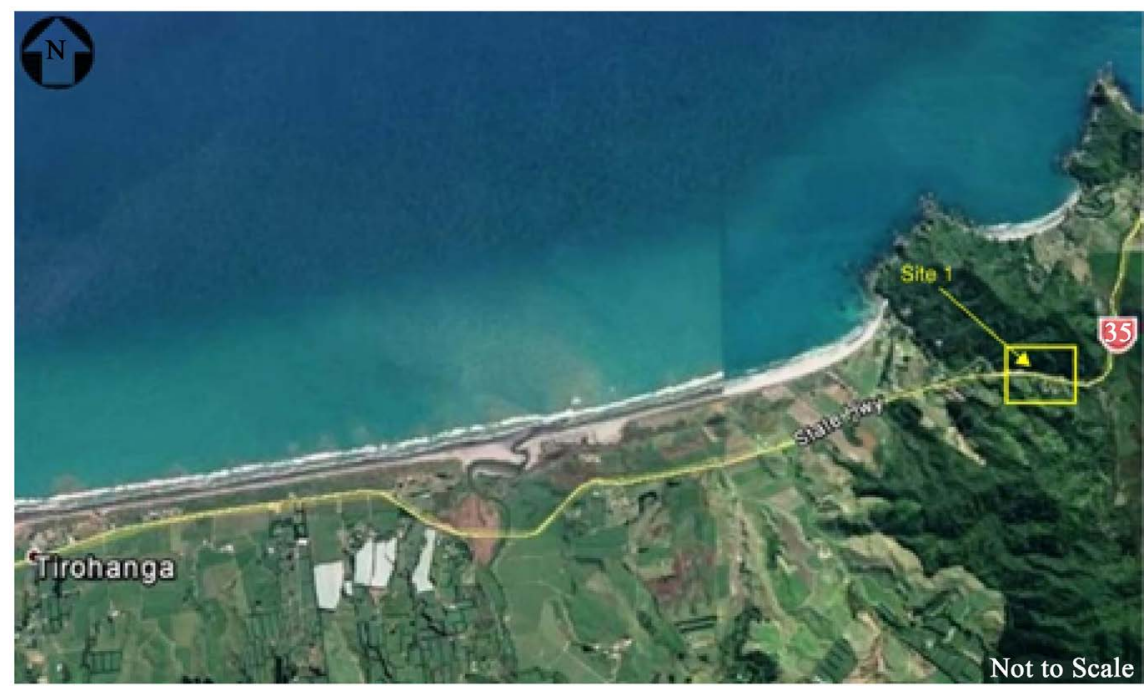

Figure 2. Site 1 location (@Google Map 2018). 


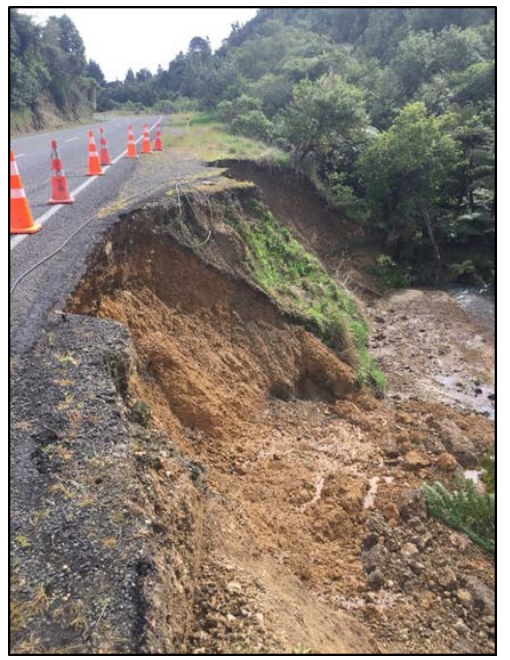

Figure 3. Site 1 under slip (erosion in the base of the road).

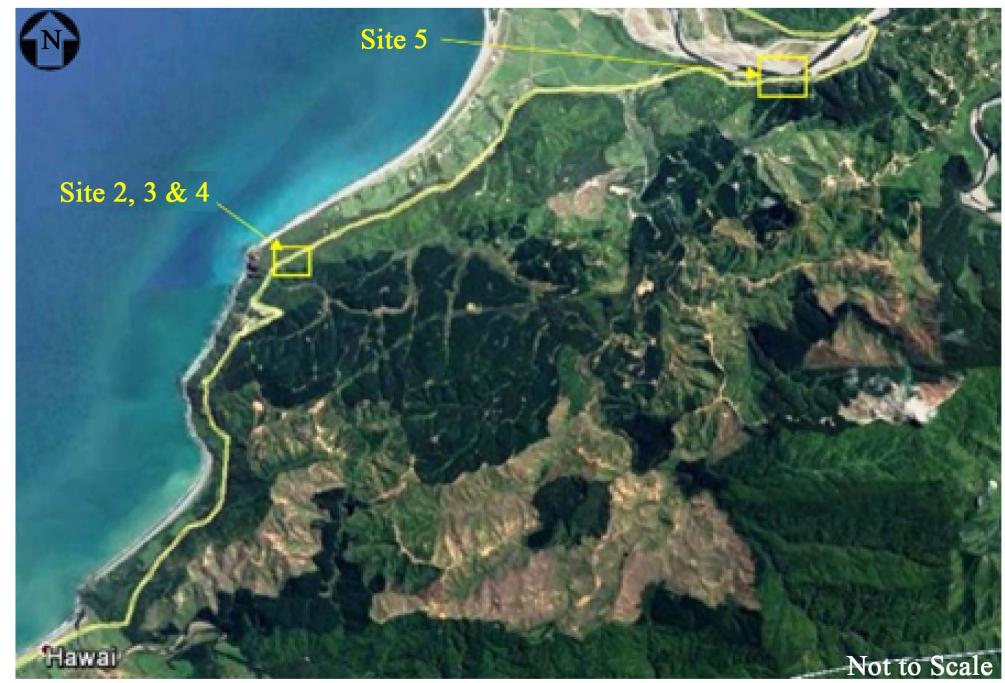

Figure 4. Sites 2 to 5 (@Google Map 2018).

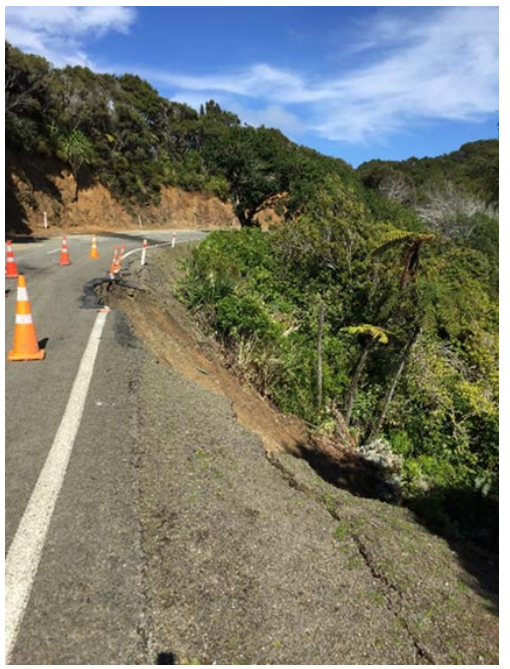

Figure 5. Under slip site 2. 
The second episode occurred in the late August 2018 when the slip regressed thus affecting a portion of the outer lane. This was damaged, causing restricted traffic. The slip is $13 \mathrm{~m}$ wide, with tension cracks located at $1.5 \mathrm{~m}$ from the edge line. The under slip affected only the top $6 \mathrm{~m}$ of the entire slope. The debris consists mostly of residual soil from highly weathered greywacke.

Close to the Site 2 under slip, other failures were recorded at the same time of the year between $500 \mathrm{~m}$ and $6 \mathrm{~km}$ away from the previous under slip (Figure 4).

Site 3 under slip measures $12 \mathrm{~m}$ wide with $2 \mathrm{~m}$ long tension cracks located 1.1 $\mathrm{m}$ away from the road edge line. The slip affected only the top $6 \mathrm{~m}$ of the slope as debris was likely stopped by the thick vegetation present below.

Site 4 over slip released a fair amount of debris estimated to be between 400 to $500 \mathrm{~m}^{3}$. The geometry follows what appears to be a wedge feature within the residual soil. Spring water was still present at the base of the gully (Figure 6).

Site 5 over slip is located approximately $9.5 \mathrm{~km}$ NNE of Hawai and measures $22 \mathrm{~m}$ in height and $10-12 \mathrm{~m}$ in width. Debris is mostly residual soil that overlies a heavy folded greywacke. The total debris is estimated to be approximately 200 $\mathrm{m}^{3}$. Some blocks are overhanging and still pose a hazard to the corridor and traffic.

\subsubsection{Sites 6 and 7}

Site 6 slip is located approximately $4.5 \mathrm{~km}$ of Omaio (Figure 7). The occurrence was at the end of August 2018. The scarp measures $13 \mathrm{~m}$ in width and $10-12 \mathrm{~m}$ in height. The failure surface slopes at $75^{\circ}$ in the upper portion and, at the base, it is almost vertical. The debris is almost entirely residual soil from completely weathered greywacke. No rocks are present within the soil matrix. Tension cracks are visible at approximately $1.7 \mathrm{~m}$ from the center line and $1.1 \mathrm{~m}$ from the crown.

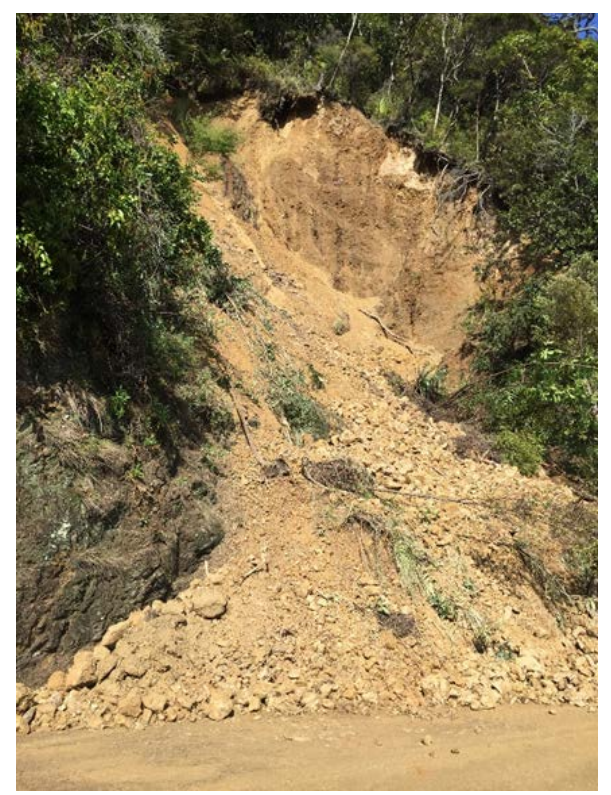

Figure 6. Over slip site 4 . 


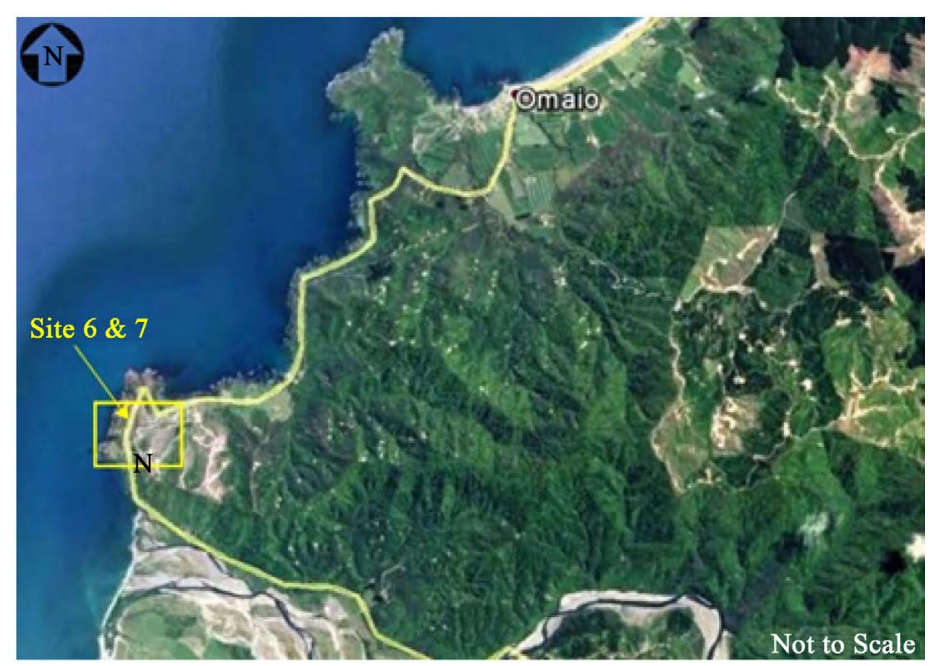

Figure 7. Sites 6 \& 7 (@Google Map 2018).

Site 7 slip is located $500 \mathrm{~m}$ north of Site 6. It occurred early September 2018 (Figure 7). The area affected by the slope failure measures $15 \mathrm{~m}$ in height and 50 $\mathrm{m}$ in width and consists of multiple semi-rotational slips. Most of the displaced material is still intact; it did not turn into loose material. The material consists of loose to medium dense clayey silty fine sand, being dark yellowish orange in color. Adjacent land use consists of forestry. The area located immediately upslope appears to have been recently harvested. As the vegetation was still developing, the shallow soils were likely reworked and left loose undermining the stability of the overall slope.

\subsubsection{Site 8}

On June 20th, 2018, an earthquake of $4.7 \mathrm{~m}$ centered $4 \mathrm{~km}$ deep and approximately $35 \mathrm{~km}$ southwest of the current rock fall location was recorded. The seismic event may have damaged the already marginally stable site and pushed it close to failure.

One month later, the heavy rain has triggered the rock fall which affected an area $30 \mathrm{~m}$ wide by $20 \mathrm{~m}$ high located approximately $1 \mathrm{~km}$ East of Cape Runaway (Figure 8). The geology of the area shows the failing slope is made of weak to moderately strong sandstone with local tuff beds and marine sandy cemented deposits (Figure 9). Jointing daylights on the road are at an angle of $45^{\circ}$. Bedding plane appears to dip gently back into the slope. Sub-vertical cracks have been identified at the time of failure, and these were likely responsible for the rock fall.

\section{Trigger Mechanisms}

\subsection{Definition}

Landslides can have several causes including geological, morphological, physical, and human ones (Cruden \& Varnes, 1996), however, there is only one known trigger (Varnes, 1978). 


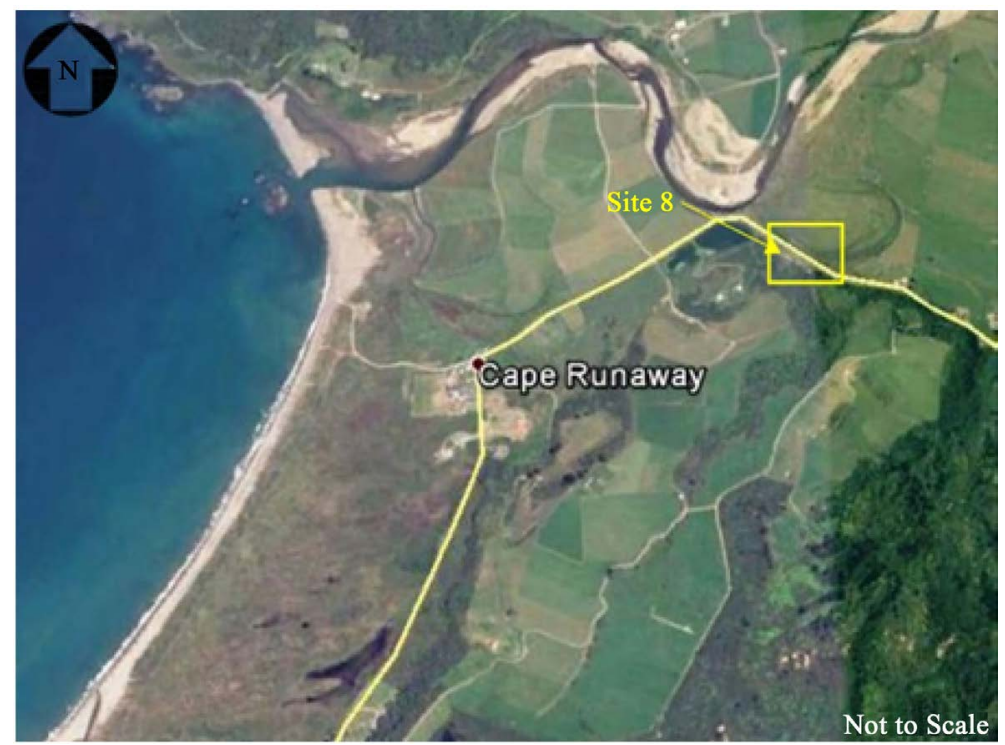

Figure 8. Site 8 (@Google Map 2018).

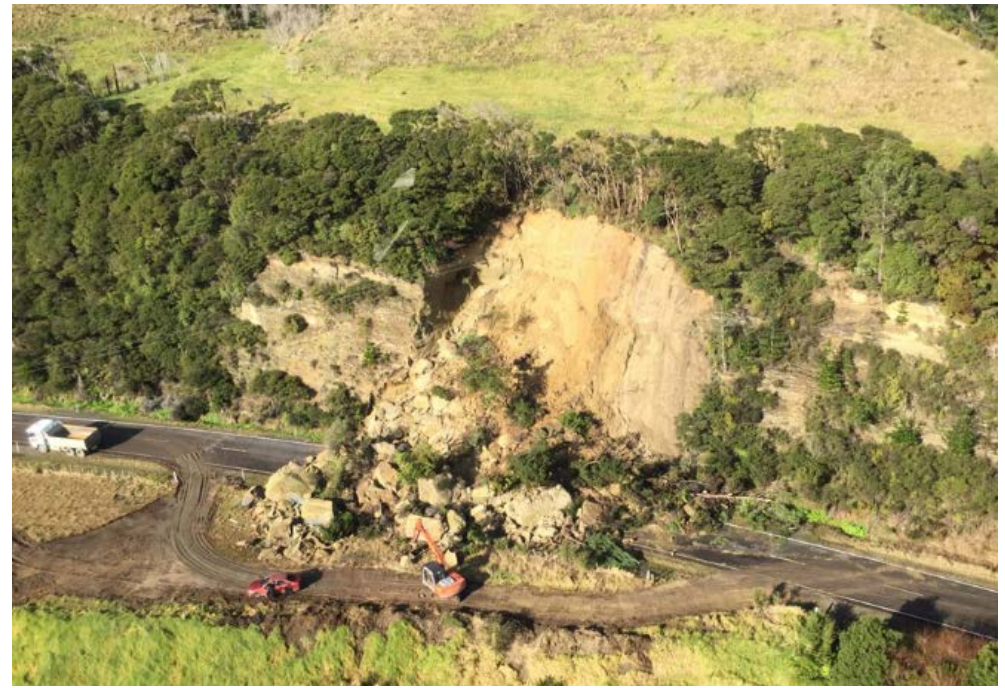

Figure 9. Site 8 rockfall (image courtesy of J. Griffith).

By definition, a trigger is an external stimulus, for example, an intense rainfall, an earthquake, a volcanic eruption, storm waves, or rapid stream erosion. All these stimuli can cause a near-immediate landslide response by rapidly increasing the stress on the slope materials, or by strength reduction of these materials (Wieczorek, 1996).

\subsection{Rainfall}

The rain data was collected from two rain stations provided by BOP East Council. Ohope 5 station is located $9.4 \mathrm{~km}$ East of Whakatane. The Hicks Bay station is $3.8 \mathrm{~km}$ northeast of the Hicks Bay settlement. Another station has been used by NIWA (Haparapara) which is located far away from the coast within the Raukumara Ranges at an altitude of $1040 \mathrm{~m}$ above the sea level. Despite its loca- 
tion, Haparapara rain gauge has been very useful in providing additional data.

Ohope 5 data has been used for the landslip at Houpoto, Whitianga, and Oroi. On July 12, no rain was recorded. However, two days before the landslide event, a cumulative $11.5 \mathrm{~mm}$ of rainfall was recorded (i.e., $5.75 \mathrm{~mm} /$ day). Severe rainfall was recorded on August 31 during the landslides at Houpoto and Whitianga with $91 \mathrm{~mm}$ falling within two days $(45.5 \mathrm{~mm} /$ day), with the station at Haparapara recording $143 \mathrm{~mm}$ the day before. On September 4, no major rainfall was recorded, whereas the data from six days before the landslip shows a cumulative rainfall of $101.3 \mathrm{~mm}(17 \mathrm{~mm} /$ day $)$.

Hicks Bay station recorded $0 \mathrm{~mm}$ of rainfall on the 22 of July, while the day after it recorded $34.8 \mathrm{~mm}$. For Waihau, the week before the landslip it recorded $181.6 \mathrm{~mm}$, which approximately equals $26 \mathrm{~mm}$. At Haparapara, the rainfall recorded on July 22nd was $63 \mathrm{~mm}$.

In some cases, rainfall does not match the time of the landslides. The difference may be related to the distance of the station from the actual location of the landslide (i.e., 50 - $60 \mathrm{~km}$ away). It appears that the Cape Runaway rockfall may have been triggered by a similar rainfall recorded the day before, because the weather front was likely moving East to West. However, it is also plausible that the intensity of the rainfall decreased by the time the bad weather reached Hicks Bay Station. This aligns with the rainfall records from the Haparapara station. Although rainfall is considered the main triggering factor, the data from the weather stations, albeit poorly reliable, does not confirm it.

\subsection{Earthquakes}

An active fault is where movement occurred within the last 125,000 years (Mazengarb \& Speden, 2000).

Among the faults of the Raukumara Peninsula, the only one that has been studied in detail is the Pakarae Fault which has moved a total of $16 \mathrm{~m}$ vertically in three separate events within the last 5500 years (Mazengarb \& Speden, 2000).

The main faults affecting the SH3 are the Kereu Fault, the Haparapara Fault, and the Motu River Fault, and these have a recurrence between 3500 and 5000 years (GNS, 2018).

The timeline of these earthquakes cannot be related to the landslides that occurred in 2018, where the only seismic event that may have affected the area was the one that occurred not far from Site 8. However, the actual rock fall happened significantly later, and therefore does not seem to be directly connected to the slope failure.

\subsection{Freight's Vibration Effects}

Despite the low level of importance, SH35 is busy by the numerous freights that transport wood logs from the Raukumara peninsula to the Tauranga Harbor.

In a soil medium, grains bind each other with a strength that is influenced by cohesion and suction, and this changes with the saturation of the ground especially during heavy rainfall events. Saturation is not the only factor that influ- 
ences the grain bond. Heavy loads from freight can also propagate into the ground and affect the behavior of the grains within the soil (Kusumawardani et al., 2018).

Vibrations are caused by the interaction between the axles of the vehicle and the different types of surface unevenness. The level of vibration increases directly with the speed of the vehicles (Ducarne et al., 2017).

The oscillation amplitude is related to the speed of trucks. Furthermore, an increase of the axial load will increase the force action on the roadbed (Patriaev, 2016). Other factors that influence the road vibration are the condition of the road, suspension type, and soil type stratification (Hunaidi, 2000).

Based on a previous study for SH35, the Highway traffic that induced ground vibration generated a forced vibration of the pavement-structure-subgrade system with the dominant frequency between 10 and $15 \mathrm{~Hz}$ (Hajek et al., 2006). There may be some merit in carrying out a study of the impact that traffic induced vibrations have on the road, and specifically, the under slopes.

\section{Conclusion}

The landslides recorded in the Bay of Plenty East on SH35 show that this type of hazard is frequent within the corridor. Most of the failures occurred on the mountain cuts to accommodate the state highways.

Despite the presence of some active faults and the poor availability of the rainfall data, heavy rainfall has been considered the main landslide trigger affecting the Raukumara Peninsula during the winter season. However, the importance of the vibration effects that are caused by the passing freight should not be underestimated especially for the under-slip section of SH35. The amplitude of vibrations caused by freight ranges between 0.0005 and $0.2 \mathrm{~g}$ (Hunaidi, 2000). According to recent studies of earthquake-triggered landslides, even a lower limit of PGA can trigger a landslide (i.e., between 0.05 and $0.07 \mathrm{~g}$ ). Occasionally, landslides were reported to have been induced by yet a lower threshold (Wang et al., 2010). Therefore, it is suggested that the freights moving along the SH35 may significantly contribute to the instability of the slope specifically for those below the road level.

As most of the slope failures occur in the wet season, rainfall can be considered the main trigger. However, the freight vibrations have an important role that the author defines it as accessory trigger mechanism.

Given that the weather condition would likely worsen due to global warming effects and the heavy freight traffic will continue, future failures are likely to be expected along the SH35. For this reason, the author suggests further studies to the effect of freight vibration onto road slopes and possible mitigation measures.

\section{Acknowledgements}

The author wishes to thank David Dobson and Tafu Tuiloma for the editing, Beca Bay of Plenty East NOC team for their support, as well as Higgins and NZTA for their kind permission to publish the material of this paper. 


\section{Conflicts of Interest}

The author declares no conflicts of interest regarding the publication of this paper.

\section{References}

Chappell, P. R. (2013). The Climate and Weather of Bay of Plenty. NIWA Science and Technology Series, No. 62.

Cruden, D. M., \& Varnes, D. J. (1996). Landslides Investigation and Mitigation. Chapter 3-Landslide Type and Processes. Transportations Research Board, No. 247, 36-75.

Ducarne, L., Ainalis, D., \& Kouroussis, G. (2017). Ground Vibration Generated by the Passing of a Truck on a Speed Bump. Rhodes Island, Greece: 6th ECCOMAS Thematic Conference on Computational Methods in Structure Dynamics and Earthquake Engineering. https://doi.org/10.7712/120117.5541.17137

GNS (2018). Active Fault Database. https://data.gns.cri.nz/af/

Hajek, J. J., Blaney, C. T., \& Hein, D. K. (2006). Mitigation of Highway Traffic-Induced Vibration. Charlottetown: Annual Conference of the Transportation Association of Canada.

Hearn, G. J., \& Hunt, T. (2011). Slope Management. Geological Society, London, Engineering Geology Special Publication, 24, 269-284. https://doi.org/10.1144/EGSP24.17

Hunaidi, O. (2000). Traffic Vibrations in Buildings. Construction Technology Update No. 39.

Kusumawardani, R., Nugroho, U., Fansuri, M. H., Mindiastiwi, T., Yuniarti, W., \& Hilmi, A. S. (2018). The Impact of Vehicle Load Inducing Vibrations on the Subgrade Soil Particle Acceleration. Journal of Engineering Science and Technology, 13, 1440-1450.

Mazengarb, C., \& Speden, I. G. (2000). Geology of the Raukumara Area (60 p.). Institute of Geological and Nuclear Science 1:250 000 Geological Map 6. Lower Hutt, New Zealand: Institute of Geological and Nuclear Sciences Limited.

New Zealand Transportation Authority (NZTA) (2018). Opotiki to Gisborne via East Cape. Corridor Management Plan 2018-2028.

Ota, Y., Hull, A. G., Iso, N., Yasutaka, I., Moriya, I., \& Yoshikawa, T. (1992). Holocene Marine Terraces on the Northeast Coast of North Island, New Zealand, and Their Tectonic Significance. New Zealand Journal of Geology and Geophysics, 35, 273-288. https://doi.org/10.1080/00288306.1992.9514521

Patriaev, A. (2016). The Vibration Impact of Heavy Freight Train on Roadbed. Procedia Engineering, 143, 1136-1143. https://doi.org/10.1016/j.proeng.2016.06.143

Varnes, D. J. (1978). Slope Movement Types and Processes. In R. L. Schuster, \& R. J. Krizek (Eds.), Special Report 176: Landslides: Analysis and Control (pp.12-33). Washington DC: TRB, National Research Council.

Wang, X., Nie, G., \& Wang, D. (2010). Research on Relationship between Landslides and Peak ground Accelerations Induced by Wenchuan Earthquake. Chinese Journal of Rock Mechanics and Engineering, 29, 82-89. https://doi.org/10.1007/s11589-010-0719-5

Wieczorek, G. F. (1996). Landslides Investigation and Mitigation. Chapter 4-Landslide Triggering Mechanisms. Transportations Research Board, No. 247, 76-90. 